\title{
Short communication: Comparison of predicted dietary phosphorus balance using bioavailabilities from the NRC (2001) and Virginia Tech model
}

\author{
X. Feng, ${ }^{1}$ J. P. Jarrett, K. F. Knowlton, R. E. James, and M. D. Hanigan \\ Department of Dairy Science, Virginia Polytechnic Institute and State University, Blacksburg 24061
}

\begin{abstract}
The objective of the current work was to use digestion coefficients from the Feng et al. (2015) model (Virginia Tech model) to calculate $\mathrm{P}$ bioavailability of common feeds used in dairy production. Compared with the bioavailability calculated by the Virginia Tech model, using the NRC (2001) P absorption coefficient of 0.64 for forages would underestimate the bioavailabilities of alfalfa hay, alfalfa silage, corn silage, grass hay, and mixed mainly legume silage. For concentrates, using the NRC (2001) P absorption coefficient of 0.70 would overestimate the bioavailabilities of corn grain but underestimate bioavailability of high-moisture corn. Two dairy diets were formulated using nutrient values from the NRC (2001): a standard diet that includes minimal by-products, and a by-product diet that has reduced corn and soybean meal which was replaced with corn gluten feed, distillers grains, hominy feed, and wet brewers grains. For each diet, total bioavailable $\mathrm{P}$ was calculated using availability values from the NRC (2001) and the Virginia Tech model. Comparison of $\mathrm{P}$ balance (the difference between required and bioavailable $\mathrm{P}$ ) for each diet was made using the 2 sets of bioavailabilities for a reference cow weighing $682 \mathrm{~kg}$, producing $38.6 \mathrm{~kg}$ of milk/d (3.5\% fat and $3.0 \%$ true protein, $100 \mathrm{~d}$ in milk), and consuming $23 \mathrm{~kg}$ of dry matter/d, yielding an absorbed $\mathrm{P}$ requirement of $59.4 \mathrm{~g} / \mathrm{d}$. The standard diet supplied 56.69 and $53.52 \mathrm{~g}$ of bioavailable $\mathrm{P}$ per day using bioavailabilities from the NRC (2001) and Virginia Tech models, respectively, resulting in a $\mathrm{P}$ balance of -2.71 and $-5.88 \pm 0.26 \mathrm{~g} / \mathrm{d}$. The by-product diet provided 75.75 and $78.47 \mathrm{~g} / \mathrm{d}$ of bioavailable $\mathrm{P}$, yielding $\mathrm{P}$ balances of 16.35 and $19.07 \pm 0.37 \mathrm{~g}$ per day, respectively, using the 2 sets of bioavailabilities. Using $\mathrm{P}$ bioavailabilities for individual ingredients that were based on the Virginia Tech model resulted in different
\end{abstract}

Received June 25, 2015.

Accepted October 26, 2015.

${ }^{1}$ Corresponding author: yangxin@vt.edu bioavailable $\mathrm{P}$ levels thus resulted in differing dietary $\mathrm{P}$ balances in a field setting.

Key words: phosphorus, bioavailability, balance

\section{Short Communication}

Phosphorus contamination of surface water can cause eutrophication, with negative effects on aquatic life. This problem can be minimized by feeding diets to animals that are balanced to just meet but not exceed their true $\mathrm{P}$ requirements. However, minimizing diet cost often results in the use of by-product feeds, which generally have high $\mathrm{P}$ content (e.g., distillers grains, corn gluten feed, and brewers grains; Ternouth, 1990). Although these diets typically have elevated dietary $\mathrm{P}$ content, the bioavailability of the $\mathrm{P}$ in the by-products is not well known. To minimize the risk of underfeeding $\mathrm{P}$, producers will often add supplemental inorganic $\mathrm{P}$ to the diet. In a survey conducted by Harrison et al. (2012), $54.8 \%$ of the respondents replied that the greatest barrier to reducing $\mathrm{P}$ in the diet was the uncertainty of $\mathrm{P}$ content of feedstuffs, and $69.7 \%$ indicated that knowing the $\mathrm{P}$ availability of ingredients from different sources would assist them in diet formulation.

The current requirement system for dairy (NRC 2001) applies common P bioavailability factors across broad classes of ingredients ( 0.64 for forages and 0.70 for concentrates) with more diversity for individual mineral supplements. Although this approach captures some of the apparent differences between ingredients, the bioavailability values assigned are poorly supported because of sparse data. The bioavailability of $\mathrm{P}$ in different feeds can be different due to grain processing (Duskova et al., 2001; Amezcua and Parsons, 2007), grain type (Benzie et al., 1959; Bravo et al., 2002; Kebreab et al., 2004), and exogenous enzymes (Knowlton et al., 2007).

Some of the observed difference in bioavailability can be explained by the form of $\mathrm{P}$ in each feed. The Hill et al. (2008) model considered 3 pools of $\mathrm{P}$ : inorganic $\mathrm{P}$ $(\mathbf{P i})$, phytate $\mathrm{P}(\mathbf{P} \mathbf{p})$, and nonphytate organic $\mathrm{P}(\mathbf{P o})$. When the model was fitted to observed data from several digestions studies, it was found that these chemical 
entities do indeed have varying digestibility in different parts of the digestive tract (Feng et al., 2015). Thus, this model can be used to calculate digestibilities for each of the 3 fractions in each part of the digestive tract and those values used to assign bioavailability values to individual feeds based on the P fractions in each feed.

The objective of the current work was to use the digestion coefficients derived by Feng et al. (2015) to calculate $\mathrm{P}$ bioavailability for common feeds used in cattle production and to determine the effect of using those factors on formulation of a standard diet and a high by-product diet for lactating cattle.

\section{Equations Used to Derive P Bioavailabilities of Common Feeds}

Bioavailable $\mathrm{P}$ values of feed ingredients were derived from the Feng et al. (2015) model based on the ruminal and intestinal digestibilities of Pp and Po using Monte Carlo simulation. For reference purposes, available $\mathrm{P}$ was assumed equal to Pi consumed plus that liberated by digestive action (i.e., $\mathrm{Pi}$ was assumed to be $100 \%$ available). Bioavailable $\mathrm{P}$ was assumed to equal total $\mathrm{Pi}$ absorption from the digestive tract. Because no ru- minal absorption was observed, total Pi absorbed from the digestive tract was the sum of absorption from the small intestine (SI) and the large intestine (LI):

$$
P_{\text {Bioavailability }}=P i_{\text {Absorbed }}=P i_{\text {Absorbed }, S I}+P i_{\text {Absorbed }, L I}
$$

where the respective absorption rates were a function of the flow of $\mathrm{Pi}$ in the respective gut segments times absorption efficiency $\left(A E_{P i S I}=0.81\right.$ and $\left.A E_{P i L I}=0.15\right)$, which was defined as the ratio of $\mathrm{Pi}$ absorbed to total amount of Pi entering the respective gut segment:

$$
\begin{gathered}
P i_{\text {Absorbed }, S I}=P i_{\text {Available }, S I} \times A E_{P i S I}, \\
P i_{A b s o r b e d, L I}=P i_{\text {Available }, L I} \times A E_{P i L I} \\
=\left(F_{P p P i, L I}+F_{P o P i, L I}+F_{P i L I}\right) \times A E_{P i L I},
\end{gathered}
$$

where available $\mathrm{Pi}$ in the SI was the sum of feed Pi plus $\mathrm{Pi}$ arising from degradation of $\mathrm{Pp}$ and $\mathrm{Po}$ in the rumen assuming phytase cleaves one molecule of $\mathrm{Pi}$ from $\mathrm{Pp}$

\begin{tabular}{|c|c|c|c|c|c|c|c|}
\hline Feed $^{1}$ & $\mathrm{~N}^{2}$ & \multicolumn{3}{|c|}{ Mean of $\mathrm{P}$ fraction } & \multicolumn{2}{|c|}{ Availability $^{3}$} & Bioavailability $^{3}$ \\
\hline Alfalfa hay & 16 & 0.553 & 0.015 & 0.433 & 0.921 & 0.213 & 0.78 \\
\hline Almond hulls & 2 & 0.855 & 0.0 & 0.145 & 0.975 & 0.198 & 0.82 \\
\hline Barley, grain & 6 & 0.147 & 0.662 & 0.192 & 0.826 & 0.183 & 0.69 \\
\hline Brewers grains, wet & 9 & 0.119 & 0.580 & 0.300 & 0.823 & 0.191 & 0.69 \\
\hline Corn gluten feed & 5 & 0.332 & 0.416 & 0.248 & 0.865 & 0.192 & 0.73 \\
\hline Corn, grain, ground dry & 9 & 0.098 & 0.728 & 0.174 & 0.815 & 0.180 & 0.69 \\
\hline Corn, grain, high moisture & 13 & 0.475 & 0.301 & 0.221 & 0.896 & 0.193 & 0.75 \\
\hline Corn silage & 4 & 0.920 & 0.0 & 0.080 & 0.986 & 0.194 & 0.83 \\
\hline Distillers grains with solubles, wet & 3 & 0.453 & 0.207 & 0.340 & 0.897 & 0.203 & 0.76 \\
\hline Distillers grains with solubles, dried & 13 & 0.451 & 0.265 & 0.285 & 0.894 & 0.198 & 0.75 \\
\hline Grass hay & 21 & 0.671 & 0.021 & 0.308 & 0.942 & 0.206 & 0.79 \\
\hline
\end{tabular}
(equation [4]) and the remainder is transferred to the Po pool. Digestion of Po was not observed in the SI.

Table 1. Phosphorus availability and bioavailability $(\mathrm{g} / \mathrm{g})$ of commonly used feeds in cattle production

${ }^{1}$ The value listed for each feed is the average from different regions of the United States. The regions were east north central (IN, IL, OH, MI, WI); east south central (AL, KY, MS, TN); Mid-Atlantic (DE, NJ, NY, PA); mountain (AZ, CO, ID, HI, MT, NM, NV, UT, WY); New England (CT, MA, ME, NH, RI,VT); Pacific (AK, CA, OR, WA); south Atlantic (FL, GA, MD, NC, SC, VA, WV); west north central (IA, KS, MN, $\mathrm{MO}, \mathrm{NE}, \mathrm{ND}, \mathrm{SD})$; and west south central (AR, LA, OK, TX).

${ }^{2}$ Number of feed samples analyzed.

${ }^{3}$ Availability was defined as the sum of inorganic $\mathrm{P}$ in the diet and that liberated in the digestive tract. Bioavailability was defined as total $\mathrm{P}$ absorbed from the digestive tract. 


$$
\begin{gathered}
P i_{\text {Available }, \text { SI }}=1 / 6 \times D C_{P p, \text { Deg }, \text { Rum }} \times P p_{\text {Feed }}+D C_{P o, \text { Deg }, \text { Rum }} \\
\times\left(5 / 6 \times D C_{P p, \text { Deg }, \text { Rum }} \times P p_{\text {Feed }}+P o_{\text {Feed }}\right)+P i_{\text {Feed }},
\end{gathered}
$$

Available $\mathrm{Pi}$ in the LI was the sum of $\mathrm{Pi}$ flowing from the SI $\left(F_{P i L I}\right)$ and degradation of $\mathrm{Po}\left(F_{P o P i, L I}\right)$ and $\mathrm{Pp}$ $\left(F_{P p P i, L I}\right)$ via microbial action in the LI:

$$
\begin{gathered}
F_{P i L I}=P i_{\text {Available }, S I} \times\left(1-A E_{P i S I}\right), \\
F_{P o P i, L I}=D C_{P o, \text { Deg }, L I} \\
\times\left\{\begin{array}{l}
5 / 6 \times D C_{P p, D e g, L I} \times\left[\left(1-D C_{P p, \text { Deg }, \text { Rum }}\right) \times P p_{F e e d}\right] \\
+\left(1-D C_{P o, \text { Deg }, \text { Rum }}\right) \times P o \\
\text { Feed }
\end{array}\right\}, \\
F_{P p P i, L I}=1 / 6 \times D C_{P p, \text { Deg }, L I} \times\left[\left(1-D C_{P p, \text { Deg }, \text { Rum }}\right) \times P p_{F e e d}\right]
\end{gathered}
$$

Thus, bioavailability can be calculated from the $\mathrm{P}$ fractions in the feed given digestion coefficients (DC) derived by Feng et al. (2015) ( $D C_{P p, \text { Deg,Rum }}, 0.923$; $\left.D C_{P o, \text { Deg,Rum }}, 0.825 ; D C_{P p, \text { Deg,LI}}, 0.301 ; D C_{P o, \text { Deg, } L I}, 0.5\right)$. A list of bioavailabilities for common ingredients is provided in Table 1. The NRC (2001) predicted constant $\mathrm{P}$ absorption coefficients for forages $(0.64)$ and concentrates (0.70). In Table 1, corn silage has the highest $\mathrm{P}$ bioavailability (0.83), whereas canola has the lowest (0.68). Compared with the bioavailability from the Virginia Tech model, using the NRC (2001) value of 0.64 for forages underestimates the $\mathrm{P}$ bioavailabilities of alfalfa hay, alfalfa silage, corn silage, grass hay, and mainly legume silage. For concentrates, using the NRC (2001) value of 0.70 for concentrates overestimates the $\mathrm{P}$ bioavailabilities of corn grain but underestimates $\mathrm{P}$ bioavailabilities of high-moisture corn. Thus, using aggregated absorption coefficients as indicated in NRC (2001) could reduce P feeding precision.

\section{Comparison of 2 Diets Using P Bioavailabilities from the NRC (2001) and Virginia Tech Models}

For diet formulation purposes, a reference state was chosen as a cow weighing $682 \mathrm{~kg}$, producing $38.6 \mathrm{~kg}$ of milk/d (3.5\% fat and 3.0\% true protein, 100 DIM), and consuming $23 \mathrm{~kg}$ of $\mathrm{DM} / \mathrm{d}$ with a total absorbed $\mathrm{P}$ requirement of $59.4 \mathrm{~g} / \mathrm{d}$. With targeted $\mathrm{NE}_{\mathrm{L}}, \mathrm{MP}, \mathrm{Ca}$, and $\mathrm{P}$ concentrations as constraints, 2 dairy diets were formulated using nutrient values from the NRC (2001): a standard diet that included minimal by-products, and a by-product diet that had corn gluten feed, distillers grains, hominy feed, and wet brewers grains substituted for a portion of the corn and soybean meal. Feed ingredients and nutrient composition of the 2 diets are listed in Table 2. For each diet, total bioavailable $\mathrm{P}$ supply was calculated using bioavailability values from the NRC (2001) and the values in Table 3. Phosphorus balance (difference between $\mathrm{P}$ requirement and bioavailable $\mathrm{P}$ supplied) was compared for the 2 sets of $\mathrm{P}$ bioavailabilities within each diet. The $\mathrm{P}$ content of commonly used by-products (e.g., distillers grains, corn gluten feed, and brewers grains at $0.5-1.0 \% \mathrm{P}$ ) is high (Udén et al., 1980), resulting in higher $\mathrm{P}$ content for the by-product diet $(0.46 \%)$ as compared with the standard diet $(0.32 \%)$. The standard diet supplied 56.69 $\mathrm{g} / \mathrm{d}$ of bioavailable $\mathrm{P}$ when calculated using bioavailability values from the NRC (2001) and $53.52 \mathrm{~g} / \mathrm{d}$ of bioavailable $\mathrm{P}$ using the values from Table 3 . The variance estimates of dietary bioavailable $\mathrm{P}$ using Virginia

\begin{tabular}{|c|c|c|}
\hline \multirow[b]{2}{*}{ Feed ingredient } & \multicolumn{2}{|c|}{$\%$, DM basis } \\
\hline & $\begin{array}{c}\text { Standard } \\
\text { diet }\end{array}$ & $\begin{array}{c}\text { High } \\
\text { by-product } \\
\text { diet }\end{array}$ \\
\hline Alfalfa silage & 14.55 & 12.07 \\
\hline Corn silage & 49.68 & 37.80 \\
\hline Corn grain, ground dry & 15.53 & 5.15 \\
\hline Soybean meal, solvent $48 \% \mathrm{CP}$ & 8.72 & 3.48 \\
\hline Blood meal, ring dried & 1.25 & 0.90 \\
\hline Whole cottonseed & 7.06 & 0.00 \\
\hline Hydrolyzed tallow & 0.96 & 0.00 \\
\hline Hominy & 0.00 & 12.30 \\
\hline Brewers grains, wet & 0.00 & 8.20 \\
\hline Distillers grains with solubles, dried & 0.00 & 12.57 \\
\hline Corn gluten feed & 0.00 & 5.27 \\
\hline Limestone & 0.96 & 0.98 \\
\hline Magnesium oxide & 0.10 & 0.10 \\
\hline Salt & 0.29 & 0.29 \\
\hline Sodium bicarbonate & 0.59 & 0.59 \\
\hline Sodium selenite & 0.02 & 0.02 \\
\hline Vitamin premix & 0.29 & 0.29 \\
\hline \multicolumn{3}{|l|}{ Nutrient composition $^{1}$} \\
\hline $\mathrm{CP}$ & 16.5 & 17.9 \\
\hline $\mathrm{NE}_{\mathrm{L}}($ Mcal $/ \mathrm{kg})$ & 1.63 & 1.61 \\
\hline $\mathrm{NDF}$ & 34.5 & 36.3 \\
\hline Forage NDF & 28.6 & 22.2 \\
\hline $\mathrm{ADF}$ & 23.0 & 21.0 \\
\hline $\mathrm{Ca}$ & 0.8 & 0.7 \\
\hline $\mathrm{P}$ & 0.32 & 0.46 \\
\hline $\mathrm{Pi}$ & 0.17 & 0.22 \\
\hline $\mathrm{Pp}$ & 0.10 & 0.15 \\
\hline Po & 0.05 & 0.09 \\
\hline Ether extract & 5.0 & 4.1 \\
\hline
\end{tabular}
Tech bioavailabilities were obtained by considering the variances of the terms used in the equations (Monte

Table 2. Standard and high by-product diets for reference cow (DMI $23 \mathrm{~kg} / \mathrm{d}, 52 \mathrm{mo}$ old, $682 \mathrm{~kg}$ of BW, $38.6 \mathrm{~kg}$ of milk/d with $3.5 \%$ fat and 3.0 true protein, 100 DIM)

${ }^{1} \mathrm{Pi}=$ inorganic $\mathrm{P} ; \mathrm{Pp}=$ phytate $\mathrm{P} ; \mathrm{Po}=$ nonphytate organic $\mathrm{P}$. 
Table 3. Comparison of the 2 diets using bioavailability values from the NRC (2001) and Virginia Tech model

\begin{tabular}{lccc}
\hline Diets & $\begin{array}{c}\text { Total } \\
\text { dietary P } \\
(\mathrm{g} / \mathrm{d})\end{array}$ & $\begin{array}{c}\text { Bioavailable } \\
\text { P supplied } \\
(\mathrm{g} / \mathrm{d})\end{array}$ & $\begin{array}{c}\text { Balance }^{1} \\
(\mathrm{~g} / \mathrm{d})\end{array}$ \\
\hline Standard diet with NRC P bioavailability & 69 & 56.69 & -2.71 \\
Standard diet with Virginia Tech model P bioavailability & 69 & 53.52 & $-5.88 \pm 0.26$ \\
Byproduct diet with NRC P bioavailability & 115 & 75.75 & 16.35 \\
Byproduct diet with Virginia Tech model P bioavailability & 115 & 78.47 & $19.07 \pm 0.37$ \\
\hline
\end{tabular}

${ }^{1}$ Balance is calculated as the difference between bioavailable $\mathrm{P}$ supplied $(\mathrm{g} / \mathrm{d})$ and absorbed $\mathrm{P}$ requirement by the reference state cow $(59.4 \mathrm{~g} / \mathrm{d})$. Variance estimates of the dietary P balance were determined for the Virginia Tech model using the reported parameter estimates (Feng et al., 2015) with a Monte Carlo simulation approach. Comparable variance estimates for the NRC model could not be determined due to lack of information.

Carlo approach). The uncertainties of dietary bioavailable P for NRC (2001) could not be determined due to a lack of information. Given an absorbed $\mathrm{P}$ requirement of $59.4 \mathrm{~g} / \mathrm{d}$ for the reference state, the standard diet yielded a $\mathrm{P}$ balance of -2.71 and $-5.88 \pm 0.26$ $\mathrm{g} / \mathrm{d}$ using the 2 sets of $\mathrm{P}$ bioavailabilities, respectively. The by-product diet supplied 75.75 and $78.47 \mathrm{~g} / \mathrm{d}$ of bioavailable $\mathrm{P}$ using bioavailabilities from the NRC (2001) and Table 3, respectively, resulting in P balances of 16.35 and $19.07 \pm 0.37 \mathrm{~g} / \mathrm{d}$, respectively. It can be seen that using $\mathrm{P}$ bioavailabilities from the Virginia Tech model provided a lower predicted $\mathrm{P}$ balance for the standard diet $(-5.88$ vs. $-2.71 \pm 0.26 \mathrm{~g} / \mathrm{d})$ but a higher predicted $\mathrm{P}$ balance for the by-product diet

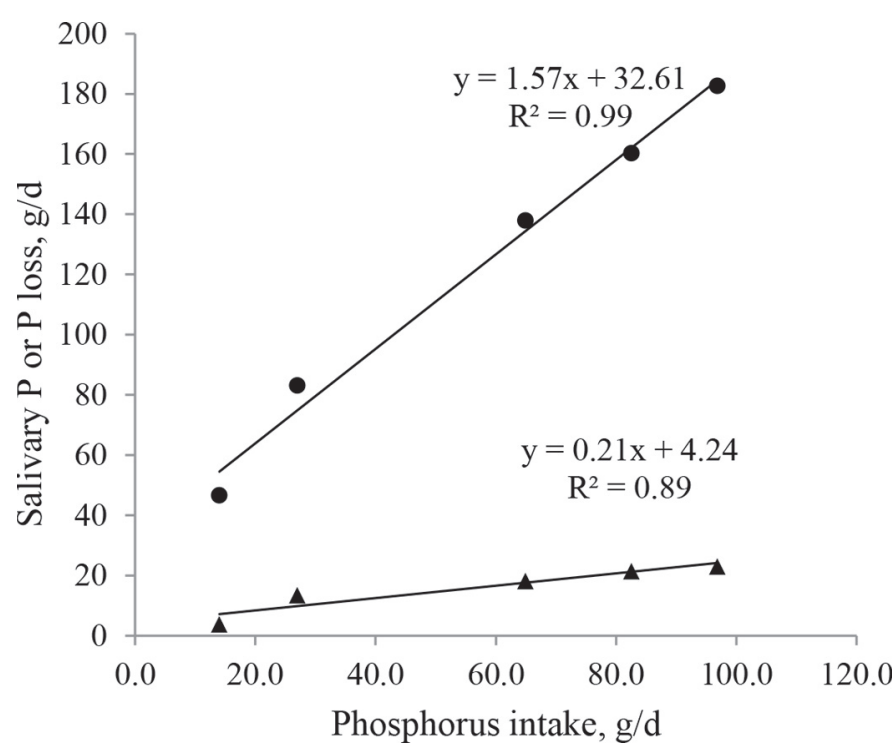

Figure 1. Salivary $\mathrm{P}$ recycling $(\bullet)$ and $\mathrm{P}$ loss $(\boldsymbol{\Delta})$ due to salivary recycling at different dietary $\mathrm{P}$ intakes. The $P$-value for salivary $\mathrm{P}$ recycling is 0.0005 , with standard errors for slope and intercept 0.098 and 6.460 , respectively; the $P$-value for P loss is 0.0154 , with standard errors for slope and intercept 0.041 and 2.682 , respectively. The root mean square errors for salivary $\mathrm{P}$ and $\mathrm{P}$ loss are 7.029 and 2.919, respectively.
(19.07 \pm 0.37 vs. $16.35 \mathrm{~g} / \mathrm{d})$ as compared with using bioavailabilities from the NRC (2001) model.

It is important to recognize that the above true absorption coefficient calculation does not consider losses of recycled salivary $\mathrm{P}$ in the gut, which is considered part of the $\mathrm{P}$ requirement, and any comparisons of model values to total-tract digestion should add the recycling losses to the unabsorbed fraction to get a fecal value. The model of Feng et al. (2015) was used to predict salivary $\mathrm{P}$ losses for a range of $\mathrm{P}$ intakes for animals at requirement, and the resulting data were regressed on $\mathrm{P}$ intake to derive an empirical prediction of the loss (Figure 1). This was completed using a young growing heifer, an older heifer, and a lactating cow with low, medium, and high milk production. Dietary $\mathrm{P}$ fractions were set to the reference diet described in Feng et al. (2015; Pp 40\%, Po 30.7\%, and Pi 29.3\%), and $\mathrm{P}$ intake was manipulated to generate $0 \mathrm{P}$ balance for each animal. Salivary recycling and loss of salivary $\mathrm{P}$ in feces were both linearly related to total $\mathrm{P}$ intake. Thus, one could calculate endogenous $\mathrm{P}$ losses due to salivary $\mathrm{P}$ recycling in the gut, at requirement, from total $\mathrm{P}$ intake.

Using the revised $\mathrm{P}$ bioavailability values of Feng et al. (2015) does affect calculated P balance and thus would affect final diet formulation if solving for $\mathrm{P}$ requirements with available $\mathrm{P}$ as a constraint. The added precision in using these values could allow diets to be more balanced, reducing the fear of P deficiency of the diet. This should result in reduced $\mathrm{P}$ loading to surface water in association with cattle production.

\section{ACKNOWLEDGMENTS}

Funding for this work was provided by USDA-Agriculture and Food Research Initiative (grant \#200955206-05267s, the Virginia Agricultural Experiment Station (Blacksburg, VA), and the Hatch Program of the National Institute of Food and Agriculture, USDA (Washington, DC). 


\section{REFERENCES}

Amezcua, C. M., and C. M. Parsons. 2007. Effect of increased heat processing and particle size on phosphorus bioavailability in corn distillers dried grains with solubles. Poult. Sci. 86:331-337.

Benzie, D., A. W. Boyne, A. C. Dalgarno, J. Duckworth, and R. Hill. 1959. The relationship between phosphorus intake and resorption and repair of the skeleton in pregnancy and lactation. J. Agric. Sci. 52:1-12.

Bravo, D., F. Meschy, C. Bogaert, and D. Sauvant. 2002. Effects of fungal phytase addition, formaldehyde treatment and dietary concentrate on ruminal phosphorus availability. Anim. Feed Sci. Technol. 99:73-95.

Duskova, D., R. Dvorak, V. Rada, J. Doubek, and M. Marounek. 2001. Concentration of phytic acid in faeces of calves fed starter diets. Acta Vet. Brno 70:381-385.

Feng, X., K. F. Knowlton, and M. D. Hanigan. 2015. Parameterization of a ruminant model of phosphorus digestion and metabolism. J. Dairy Sci. 98:7194-7208.

Harrison, J., K. F. Knowlton, B. James, M. D. Hanigan, C. Stallings, and E. Whitefield. 2012. Case study: National survey of barriers related to precision phosphorus feeding. Prof. Anim. Sci. 28:564568

Hill, S. R., K. F. Knowlton, E. Kebreab, J. France, and M. D. Hanigan. 2008. A model of phosphorus digestion and metabolism in the lactating dairy cow. J. Dairy Sci. 91:2021-2032.

Kebreab, E., J. A. N. Mills, L. A. Crompton, A. Bannink, J. Dijkstra, W. J. J. Gerrits, and J. France. 2004. An integrated mathematical model to evaluate nutrient partition in dairy cattle between the animal and its environment. Anim. Feed Sci. Technol. 112:131-154.

Knowlton, K. F., M. S. Taylor, S. R. Hill, C. Cobb, and K. F. Wilson. 2007. Manure nutrient excretion by lactating cows fed exogenous phytase and cellulase. J. Dairy Sci. 90:4356-4360.

NRC. 2001. Nutrient Requirements of Dairy Cattle. 7th rev. ed. Natl. Acad. Press, Washington, DC.

Ternouth, J. H. 1990. Phosphorus and beef production in northern Australia. 3. Phosphorus in cattle - A review. Trop. Grassl. 24:159-169.

Udén, P., P. E. Colucci, and P. J. Van Soest. 1980. Investigation of chromium, cerium and cobalt as markers in digesta-Rate of passage studies. J. Sci. Food Agric. 31:625-632. 